SŁAWOMIR DoROCKI

Pedagogical University of Cracow, Poland

\title{
Contemporary Trends in the Development of the Pharmaceutical Industry in the World
}

\begin{abstract}
The pharmaceutical industry remains today a prominent high-technology sector of the economy, and consistently maintains its competitiveness on the world market at a very high level. Similarly to aircraft and spacecraft manufacturing and the electro-energy industry, pharmaceutical industry belongs to a group of innovative high-technology industries, which are based on scientific research results processed for industrial activities. The purpose of this study is to present and analyse global trends currently observed in the pharmaceutical industry in the world. In an era of increasing globalization, new prime movers of the development of the pharmaceutical industry are the countries from peripheral regions, mainly members of the BRICS group. For this reason, this article focuses on the emerging Asian and Latin American markets, next to the United States and countries of Western Europe. At the beginning of the twenty-first century, Brazil and China deemed the stimulation of the pharmaceutical industry one of the prime determinants of their future economic development. The following paper at first presents characteristics of the pharmaceutical industry products: innovative and generic medicines, medications available without prescription, biological agents, biosimilars and pharmaceutical substrates. Furthermore, the author specifies the properties and rates the dynamics of changes that are taking place in the global pharmaceutical market, while explaining the specifics of the relocation of the pharmaceutical industry. By comparing the number of publications in the field of pharmacy in selected countries of the world, the author confirmed the increasing importance of this industry on the global economy. In the last part of the article, the author presents the structure, number and distribution of clinical trials on a global scale. To illustrate the trends currently taking place in the development of the pharmaceutical industry, the author used raw statistical data in the field of pharmacology and literature on the subject.
\end{abstract}

Key words: BRIC; clinical trials; pharmaceutical industry; relocation; USA

\section{INTRODUCTION}

The knowledge-based economy is becoming the next stage of economic development of the world, after the post-industrial one (Borowiec, Dorocki, Jenner, 2009). Knowledge and information are today the priority for economic development and, as a consequence, they determine the production and distribution of goods and services (Kilar, 2008; Dorocki, Świętek, 2013). Today, after a period of boom in the IT industry, industries associated with healthcare (biotechnology, pharmacy) are seen as the most important and 
fastest-growing sector of the high technology economy (Kilar, 2009; Dorocki, Jastrzębski, 2012). The pharmaceutical industry is now recognized as one of the most important sectors of high technology economy and it is an important factor in the socio-economic development and in shaping of the knowledge-based economy (Gierańczyk, Rachwał, 2012; Rachwał, 2013). Today, as a result of globalization and the relocation of production activities, regions previously seen as peripheral become increasingly important in innovative sectors of economy, such as the pharmaceutical industry. This applies mainly to the BRIC countries (Brazil, Russia, India and China), where today we are witnessing a boom in the market of medicinal products and increasing global connections (Raźniak, 2012; Raźniak, Winiarczyk-Raźniak, 2013). This increase involves the location of investment, both domestic and foreign, associated with the production of medicines, which in turn activates the development of local research sector.

The purpose of this paper is to present trends that are occurring today in the global pharmaceutical industry and in the pharmaceutical drug market. The analysis focuses on the U.S. market, which is the largest pharmaceutical market in the world, as well as on emerging markets, such as Asia and Latin America. The analysis uses statistical data related to the size and location of the production of drugs, obtained as raw data, as well as developed indicators from the literature on the subject.

\section{THE PHARMACEUTICAL INDUSTRY AND ITS PRODUCTS}

The pharmaceutical industry is defined as business activity that involves researching, developing, manufacturing and marketing of products used for medical and prophylactic purposes in humans or animals. For statistical purposes, both in Europe and in the U.S., pharmaceutical drugs are all medicines produced by the pharmaceutical industry, including products that are developed using biotechnology. So the main products of the pharmaceutical industry are medicines and biological agents, which are substances intended for the use in diagnostics, treatment, mitigation or prevention of diseases. There are chemical medicines (pills, capsules, vials, ointments etc.) or biological medicines (vaccines, therapeutic proteins, immune serums, tissues etc.). Currently, the pharmaceutical industry is mainly geared to the production of drugs used in the treatment of cancer, in diseases associated with the cardiovascular system, respiratory system, digestive system, in diabetes, hypertension, mental disorders and immune system disorders, e.g. HIV.

Products of the pharmaceutical industry are divided into groups associated with the various phases of the implementation of the drugs. Different types of drugs are described below.

The first type are innovative medications, both chemical and biological, developed as a result of intensive scientific research and development (R\&D) and clinical trials on humans and animals. Their production is based on patents and other forms of intellectual property rights and on investments necessary to put the product on the market. These drugs, just as the entire pharmaceutical industry, are highly dependent on the development of new medicines 
that will replace older drugs with expired patent term. The cost of introducing a new drug to the market in the U.S. is estimated to be between 0.5-2 billion U.S. dollars. On the basis of expenditure incurred on R\&D by 100 largest pharmaceutical companies in over 10 years, the average cost to market a new drug is 1,967.46 million USD (Fig. 1).

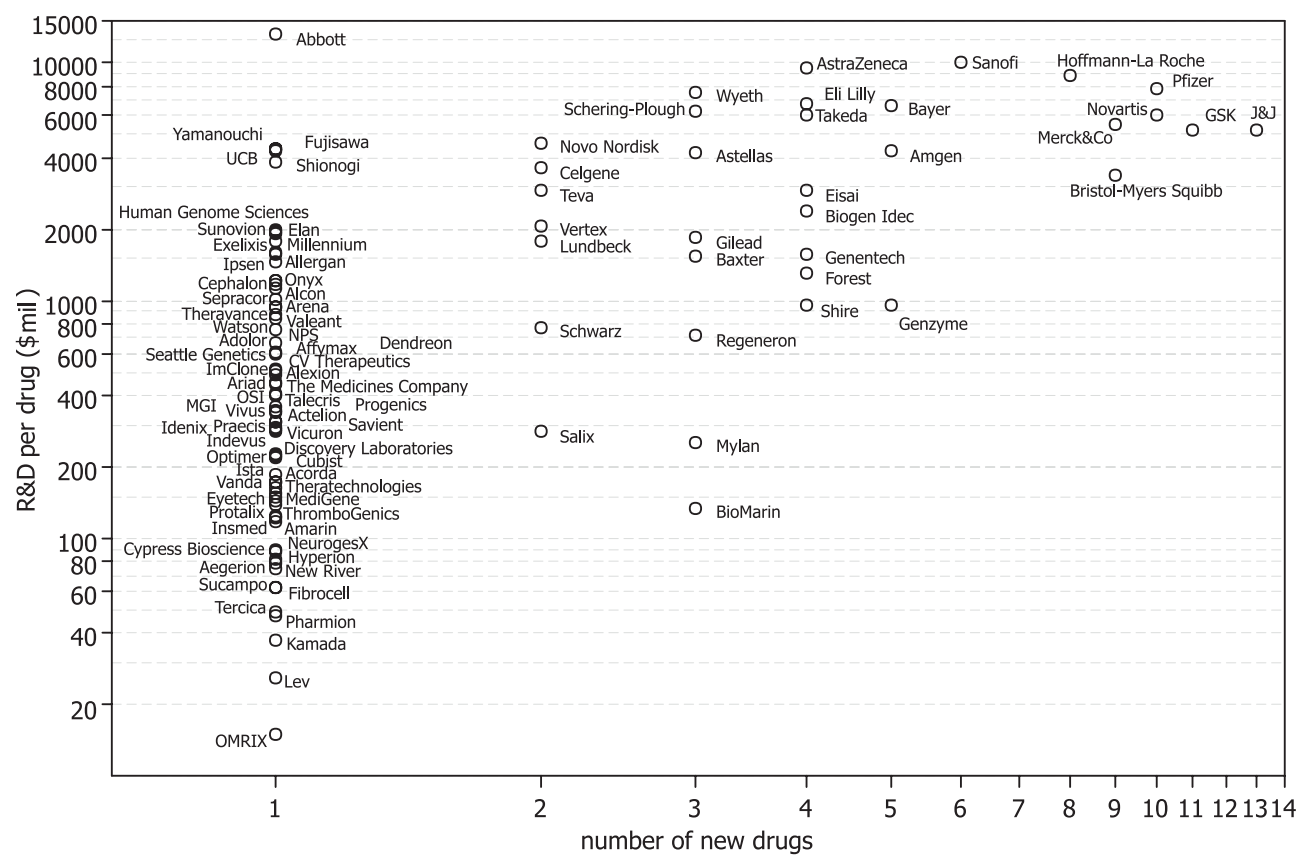

Fig. 1. The cost of introducing a drug on the market by 100 largest pharmaceutical companies in years 2002-2012

Source: own elaboration based on the data obtained from FORBES

Significant costs, especially with a large number of drugs, result from the fact that only one of 1000 compounds from the pre-clinical tests phase goes into actual clinical trials, and then one in five is approved, while only two out of ten marketed drugs generate income that outweighs the costs of research and development. The list of the costs of drugs shows how failure to put new medicines on the market generates approximately $49 \%$ of direct costs and $70 \%$ of the capitalized costs (Tab. 1). However, as demonstrated by the statement of expenditure on research per number of drugs since the mid-twentieth century, you can see a clear downward trend (Fig. 2). This is mainly due to technological and scientific progress and the increasingly common outsourcing of research (Higgins, Rodriguez, 2006; Howells et al., 2008) and relocation of costly stages of research (e.g. clinical trials) to lower cost countries (e.g. India, China, Poland). 
Tab. 1. Development costs for NMEs and biologics approved in years 1990-2008

\begin{tabular}{|l|c|c|c|c|}
\cline { 2 - 5 } \multicolumn{1}{c|}{} & \multicolumn{2}{c|}{ Direct costs } & \multicolumn{2}{c|}{ Capitalized costs } \\
\cline { 2 - 5 } \multicolumn{1}{c|}{} & $\$$ mil & percent of total & $\$$ mil & percent of total \\
\hline $\begin{array}{l}\text { Basic research through } \\
\text { preclinical }\end{array}$ & 60 & $17 \%$ & 186 & $15 \%$ \\
\hline $\begin{array}{l}\text { Clinical through regulatory } \\
\text { approval }\end{array}$ & 109 & $34 \%$ & 189 & $15 \%$ \\
\hline Allocated failures & 166 & $49 \%$ & 866 & $70 \%$ \\
\hline Total per approved drug & 355 & $100 \%$ & 1.241 & $100 \%$ \\
\hline
\end{tabular}

Source: Tufts CSDD cited in Malorye Allison, 2012

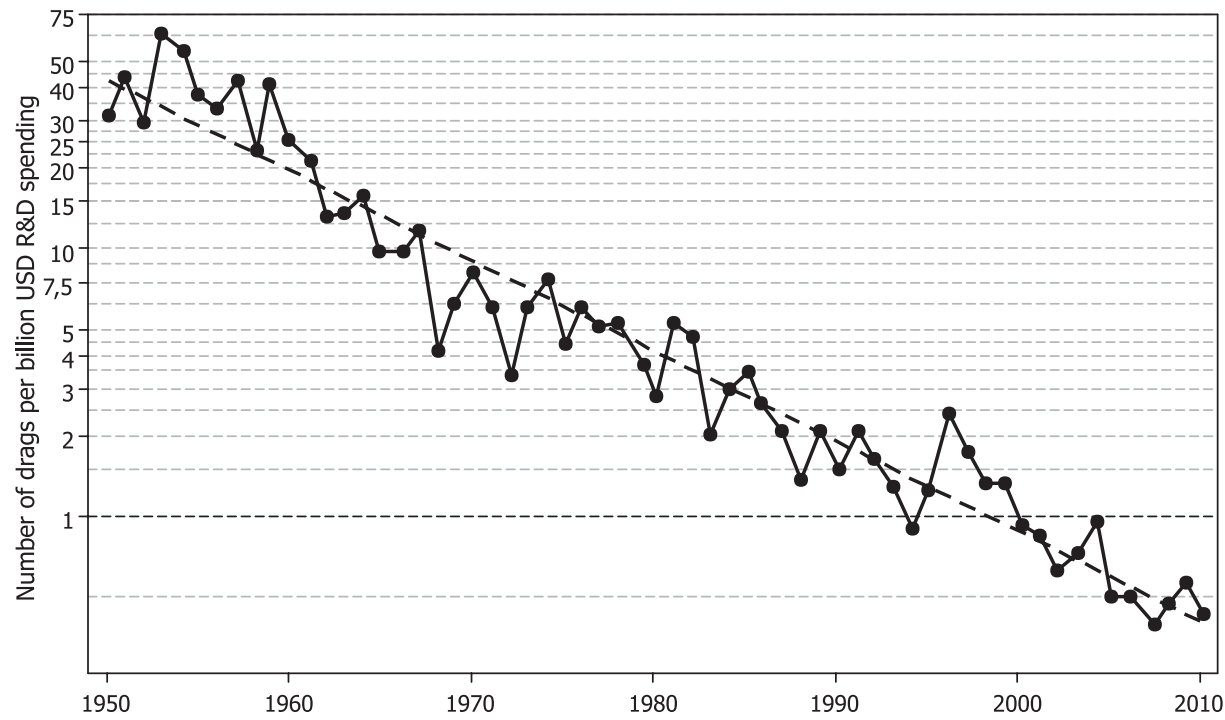

Fig. 2. The number of new drugs approved by the US Food and Drug Administration (FDA) per billion US dollars (inflation-adjusted) spent on research and development (R\&D) in years 1950-2010

Source: own elaboration based on Scannell et al., 2010

Another type of pharmaceutical products are generic drugs, commonly called generics. These are the cheaper alternatives of original medicines, for which pharmaceutical plants no longer have licenses and which are not protected by patent law. These drugs should contain the same active ingredient as the original drug, but they may be different in terms of the excipients content. Generics are therefore cheaper by about $80-85 \%$ than the original drugs. The formulation of their composition does not incur high costs for the manufacturers and there is no need to duplicate clinical trials in order to approve the drug on the market. This translates into a significant attractiveness of generic drugs for the emerging markets - particularly in Asia (India and China). The share of generics in the pharmaceutical industry is growing by about $15 \%$ per year according to BCC Research report. Generics now account for approximately $35 \%$ of the market in developed countries (about $70 \%$ of prescription drugs and in retail sales), but their share varies in different countries. In the United States, the share 
of generics is growing by $1.54 \%$ per year (with the share of $20 \%$ in the market), while in China, the increase is about $20 \%$ with $63 \%$ market share. In the developing world, the share of generics in the market increased by: $1.12 \%$ in Latin America, $0.38 \%$ in the Middle East and in South Africa, 0.31\% in Asia (Kaplan et al., 2013).

An important part of the global pharmaceutical industry are medicines available without prescription over-the-counter (OTC). After these pharmaceuticals have been approved by national regulatory authorities, they may be used for self-medication. These drugs are distributed not only in pharmacies but also in a variety of outlets, such as grocery stores, chemists etc. Due to their general accessibility and widespread use $(90 \%$ of doctors recommend their use), it is expected that the global OTC market will increase in 2015 by 70 billion US dollars. According to estimates from the Consumer Healthcare Products Association, retail sales of OTC drugs in the United States in 2010 was worth $\$ 17$ billion, or almost $\$ 175$ per person, and has established more than 3 billion increase over the period of ten years. Despite the economic recession of 2008, the interest in OTC drugs does not fade and shows an upward trend. This situation forced the governments of individual countries to reduce expenditure on health care, including reduction of drug reimbursement in this group of medicines.

An important product of the pharmaceutical industry are currently pharmaceutical substrates, defined as active pharmaceutical ingredients (APIs) and excipients used in the manufacture of drugs. It is expected that the pharmaceutical market development will result in an increase in pharmaceutical substances sales by approximately $7.9 \%$ by 2015 , mainly in the region of North and South America, as well as Europe, Asia and the Pacific. The development of new medical technologies stimulates the demand for APIs and for import of raw pharmaceutical ingredients from emerging markets. China and India currently provide more than $40 \%$ of APIs used in drugs sold in the United States and Europe, and they expect this share to increase to $80 \%$ in 10 years.

The next type of product of the pharmaceutical industry are biological agents often referred to as "biotech" drugs, "large-molecular weight" drugs or "biopharmaceuticals". Unlike chemically synthesized drugs, which have a well-defined structure and can be precisely verified, biological drugs are derived from living organisms (humans, animals, plants or micro-organisms), and therefore they are much more complex in structure and thus difficult to characterize accurately. These medicines, for example as vaccines, are designed and manufactured using modern biotechnology and they are used only in medical centres (hospitals, clinics etc.). Biological products also include materials used for transplantation, obtained as a result of extensive clinical trials, which entail a long period, an average of 10-15 years, of putting the drug on the market and the high costs amounting to 1.2 billion U.S. dollars. The market of biological drugs and originators is subject to intellectual property rights and is associated with a huge investment risk.

Another product manufactured with the use of biotechnology and associated mainly with genetic techniques and DNA recombination are biosimilars, known as follow-on biologics. Biosimilars are thus another versions, copies, of biological drugs. The legal requirements of drug registration and the costs of production result in the high costs of the introduction of these medications on the market, which amount to 75-250 million per drug (Calo-Fernández, 
Martínez-Hurtado, 2012). Therefore, even when the market of biosimilars will grow and the patents for biologics will expire, the decline in prices will not be as large as in the case of generic drugs, and the prices will be approximately $65 \%-85 \%$ of the initiator prices. In 2011 , biosimilars accounted for approximately $36 \%$ of the market of biological medicines. They are mainly manufactured in Europe and in the U.S., but also China and India have a growing share in their production (McCamish, Woollett, 2012).

\section{THE GLOBAL PHARMACEUTICAL MARKET}

The pharmaceutical industry, in comparison with other sectors of economy (perhaps only in comparison with defence industry), operates not only on the basis of market conditions (demand-supply), but it is also governed by numerous laws and regulations on safety, quality, patents etc. Until 1970, this industry was developed at a relatively small scale. However, with the emergence of new technologies and the discovery of new drugs, the industry began to grow at a very fast pace. This was due to the growing demand for drugs associated with the ageing of population, and the increasing access to health services in developing countries, as well as to the extension of the pharmaceutical offer. Pharmaceutical companies produce not only drugs, but also supplements and health aids. Due to the growing demand for pharmaceutical products and the large number of players on the pharmaceutical market, there is a huge competition in this industry. Analysing market values of the largest corporations in the world, we can see that corporations representing health care, which are mainly the representatives of companies involved in the pharmaceutical industry, have the average value of approximately 30.0 billion U.S. dollars, while the average is 20.9 billion U.S. dollars. However, pharmaceutical companies, as well as banks worldwide, have the highest average market value of associated corporations - 37.7 billion USD (average is 21.5 billion USD) (Zioło, 2006). That strong concentration of capital in the pharmaceutical industry is associated with very high costs of research and development and the high-risk investment, therefore it is practically the only way to stay on the global market (Rachwał, 2003). Thus, it can be concluded that the production of pharmaceuticals in the world has been dominated by large multinational corporations, operating globally through the network of interdependent companies and businesses. The battle for pharmaceutical markets is between pharmaceutical giants that use an increasing number of new strategies. These strategies include mergers and acquisitions, which allow the penetration of ever new areas of the pharmaceuticals world (Tobolska, Matykowski, 2006).

According to the WHO, the global pharmaceutical market in 2013 was worth about 300 billion U.S. dollars, and its value in the next three years is expected to grow to 400 billion U.S. dollars. Sales of products of the pharmaceutical industry worldwide is increasing by about $7.5 \%$ per year and in 2014 it is expected to reach 1,159 billion dollars ( 852 billion U.S. dollars in 2009). As mentioned earlier, the reasons for such a large increase in the drug market are both the economic development and prosperity of societies in developing countries, 
as well as the extension of life expectancy and the ageing of the population in developed countries. Another causative factor is the increasing interest of investors in the drug markets after the commercial success experienced by Viagra and Pfizer.

The increase in the drug market is geographically diversified and takes its course differently in different regions of the world. The largest increase in recent years was reported in countries of Eastern and Central Europe - about 9.7\% per annum, and in the Middle East and Africa $-8.6 \%$. They are followed by American markets with 7.3\%, Western Europe 6.8\%, while the increase in sales of drugs in the Asian market is approximately $4.9 \%$. According to the report Global Pharmaceutical Market Forecast to 2012, in recent years there is a growth of markets in developing countries, which are increasingly focused on biotechnology-based drugs and a strong increase in the production of generic drugs. Despite these changes and its decreasing share, North America remains the largest pharmaceutical market with approximately 33\% of global sales in 2010 (46\% in 2003). However, it can be expected that this percentage may be visibly reduced in the coming years due to the expiry of key pharmaceutical patents. For similar reasons, also the sales level in Western Europe may decrease in the near future, but it will be offset by the emerging markets in Central and Eastern Europe, which will allow Europe to maintain the $30 \%$ share in the global pharmaceuticals market $27 \%$ in 2003). The large and so far unexploited demographic potential, together with the observed economic growth in the major countries of Asia and the Pacific, will affect the development of the pharmaceutical market in this region of the world in the near future. This applies both to developed markets such as Japan, which has a $18 \%$ share in the drug market, and to China with its 6.5\% share. Growth is also expected in the Latin American markets (4\% in 2003 and $7 \%$ in 2010). This increase will be generated mainly by two countries: Brazil and Mexico, which belong to the fastest-growing pharmaceutical markets in the world. According to IMS Health Market Prognosis of 2013, the Latin American market will reach an increase of 10 $13 \%$ in years 2014-2017.

The change of the location trends in world's pharmaceutical markets are associated with major infrastructural and financial constraints. Relocation of the pharmaceutical industry and related investments are subject to high risk. This applies mainly to investments in new products and new pharmaceutical companies. The big disadvantage is the period between making the investment and putting the product on the market (the pipeline). It is assumed that the average period between the beginning of research on a new medicine and placing it in pharmacies is 10 to 20 years, and the bureaucratic process of registering the drug lasts from 1 to 1.5 years (Weyzig, 2004). In addition, in order to sell the drug in other countries further research must be carried out, which often means the re-verification of the effectiveness of the drug. Institutions supervising the drug market and carrying out controls have the power to remove the drug from the market due to even a small number of reported cases of adverse reactions or objections raised by the competition, or to remove the product from the list of reimbursed medicines.

A characteristic feature of the modern pharmaceutical industry is its very high concentration. Ten largest pharmaceutical companies control one-third of the market, with revenues of 10 billion U.S. dollars. This concentration also refers to the spatial localisation of 
pharmaceutical companies. The pharmaceutical industry is mainly concentrated in developed countries. Six of the ten largest pharmaceutical companies are located in the United States and Western Europe (Fig. 3). The largest in terms of size are companies from the USA and Japan, but there is a noticeable gap regarding the volume of sales if compared with the leaders (Johnson \& Johnson, Pfizer and Novatis). If it comes to the volume of expenditure on research and development, this gap is smaller and the 50 largest companies have shares that are more proportional to their position in the ranking. This is associated with benefits in the scale of the largest pharmaceutical companies.

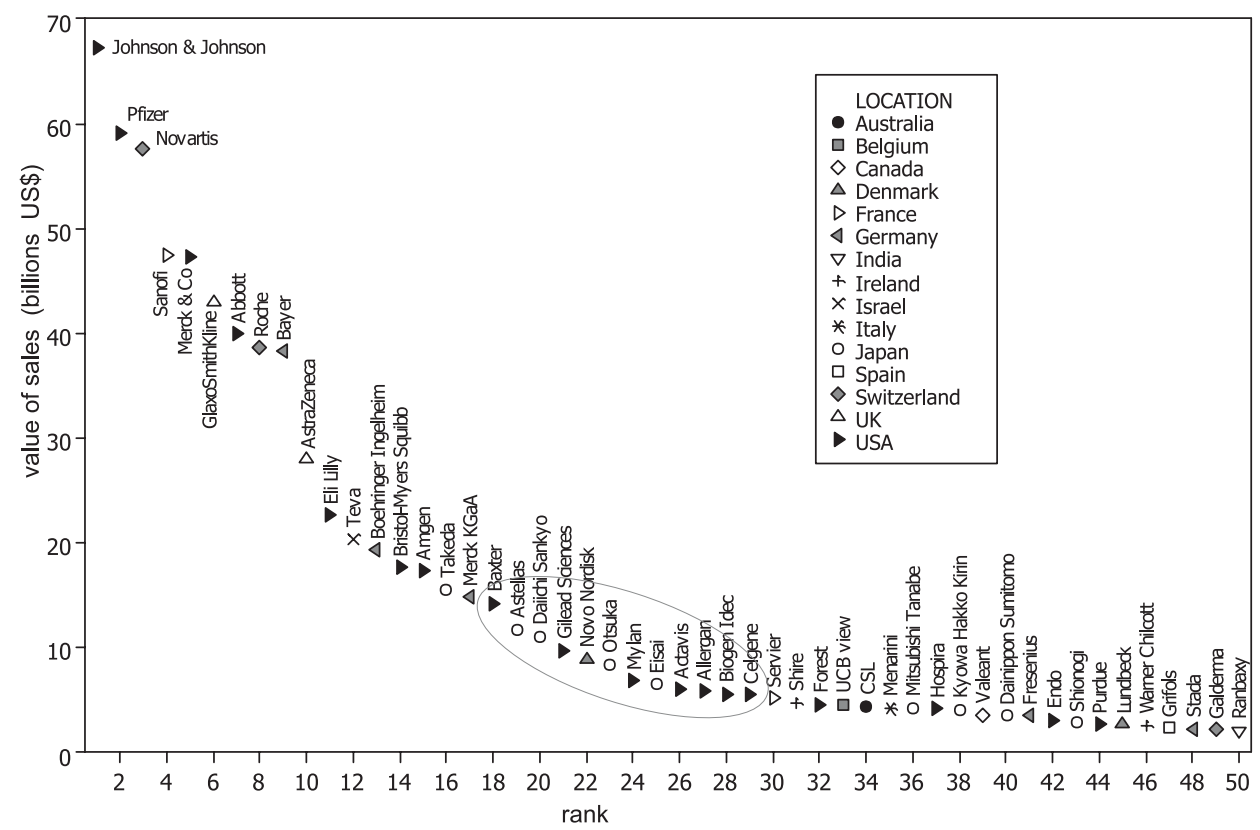

Fig. 3. The largest pharmaceutical companies by volume of sales and location of the headquarters in 2013

Source: own elaboration based on the data obtained from FORBES

Also, when comparing the number of pharmaceutical companies registered with the commercial portal Biotechgate, i.e. companies that potentially use biotechnology techniques for the production of biological medicines, you may notice the predominance of U.S. enterprises: 251 companies in 2011 (Fig. 4). The next country is Italy with 107 registered companies. Other countries with the highest number of pharmaceutical companies aredeveloped countries of Western Europe (United Kingdom, Germany, Switzerland, Spain, Sweden, France), Asia (South Korea and Japan) and Canada. The only developing country in terms of both number and value of sales is India, which, due to its economic and demographic potential, can become a global producer of drugs in the future. 
According to the International Federation of Pharmaceutical Manufacturers Associations (IFPMA), the importance of developing countries in the pharmaceutical market has been growing in recent years. These countries not only attract foreign investment of the pharmaceutical sector, but they also develop their own research. This group of countries from outside of Europe and North America is dominated by China, where in the past 10 years there has been a continuous increase of investment in early stage research. Other countries with a significant increase in the pharmaceutical industry are: South Korea, India and Brazil. China, South Korea and India together have a significant share (over 10\%) in phase I of clinical trials ${ }^{1}$.

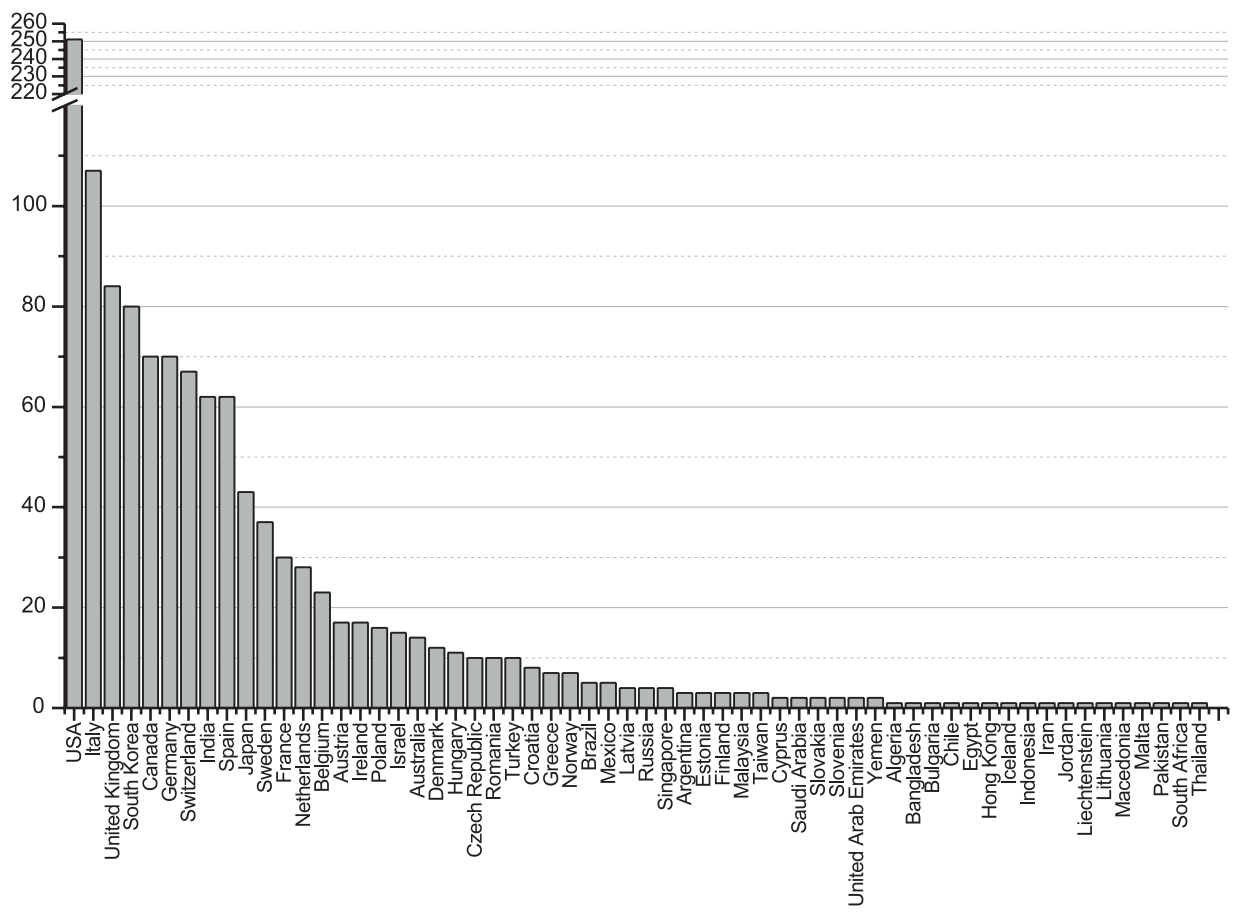

Fig. 4. Number of pharmaceutical companies

Source: own elaboration based on the data obtained from Biotechgate

${ }^{1}$ Phase 0 : Exploratory study involving very limited human exposure to the drug, with no therapeutic or diagnostic goals (for example, screening studies, microdose studies). Phase 1: studies that are usually conducted with healthy volunteers and that emphasize safety. The goal is to find out what the drug's most frequent adverse events are and, often, how the drug is metabolised and excreted. Phase 2: studies that gather preliminary data on effectiveness (whether the drug works in people who have a certain disease or condition). For example, participants receiving the drug may be compared with similar participants receiving a different treatment, usually an inactive substance (called a placebo) or a different drug. Safety continues to be evaluated, and short-term adverse events are studied. Phase 3: studies that gather more information about safety and effectiveness by studying different populations and different dosages and by using the drug in combination with other drugs. Phase 4: studies occurring after FDA has approved a drug for marketing. These include postmarket requirement and commitment studies that are required of or agreed to by the sponsor. These studies gather additional information about a drug's safety, efficacy, or optimal use. Source: http://www.clinicaltrials.gov. 
Since the mid-twentieth century there has been a surge in the number of scientific publications in the field of pharmacy (Fig. 5A). This confirms the growing importance ofindustry in the global economy, and shows the innovative nature of the industry. A particularly strong increase in number of publications begun after 2000. In terms of countries, an increase of medical publications is noticeable in China. Globally, the first place in terms of the number of studies in the field of pharmacy belongs since 1990s to the United States. However, in the first decade of the twenty-first century China left behind the former leaders in pharmaceutical research: Germany and the UK (Fig. 5B). Similarly, India and Brazil have reached similar values in the number of publications as current pharmaceutical potentate - Switzerland. These values confirm not only the growing importance of developing countries in the production of medicines, but also the increase of their participation in research and development, which previously took place exclusively in countries hosting corporate headquarters.
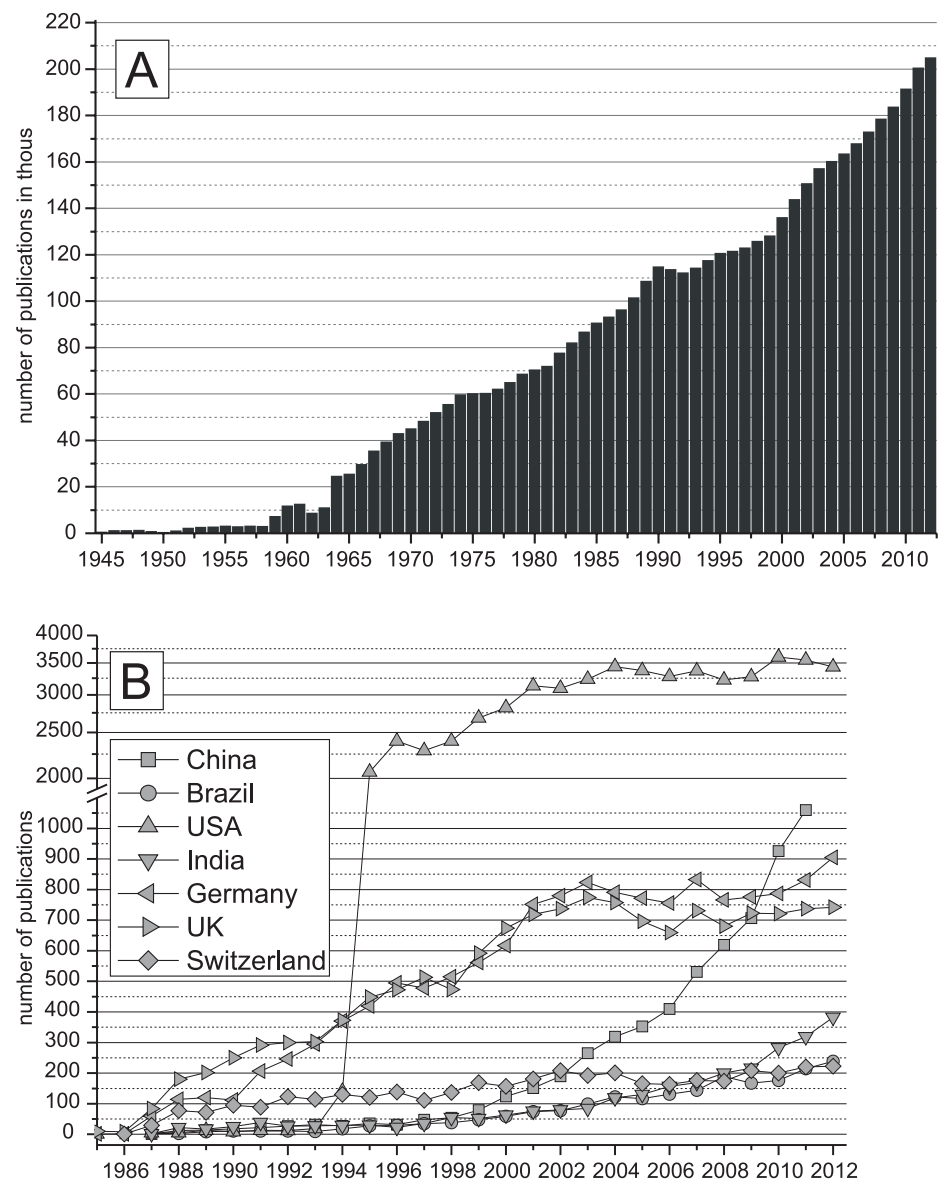

Fig. 5. The number of publications in the field of pharmacy (A) and the number of publications in the field of clinical pharmacy for selected countries (B) 
The development of pharmacy research projects in developing countries is also the result of legal restrictions for international companies wanting to enter the market in those countries. Such restrictions often force companies to commission research in these countries, which in turn results in a significant increase in the share of developing countries in global phase II and III of clinical trials (Schipper, Weyzig, 2008). There was no location of production of drugs from the Blockbuster group, i.e. drugs that generate annual sales of at least 1 billion U.S. dollars. However, despite some difficulties in free relocation of pharmaceutical companies, the international capital in the pharmaceutical market induces a significant innovation growth in developing countries. The main advantages for developing countries resulting from the relocation of the pharmaceutical industry are the development of research contracts, additional funding for hospitals and clinical research centres and keeping experienced researchers in such centres. In addition, the infrastructure used in clinical trials and the accelerated introduction of new drugs on the market are direct benefits for patients. The development of pharmaceutical companies could result in the creation of a network of institutions that could carry out a full range of research and development, which would be the opportunity to develop new treatments for diseases and to release developing countries from the domination of the U.S. and Europe. However, it is noted that the increasing outsourcing and setting up of Contract Research Organisations (CROs) associated with clinical trials in developed countries can lead to unethical activities, such as the use of people involved in the trials without their consent, and conducting research without adequate qualifications in violation of international regulations (Schipper, 2009).

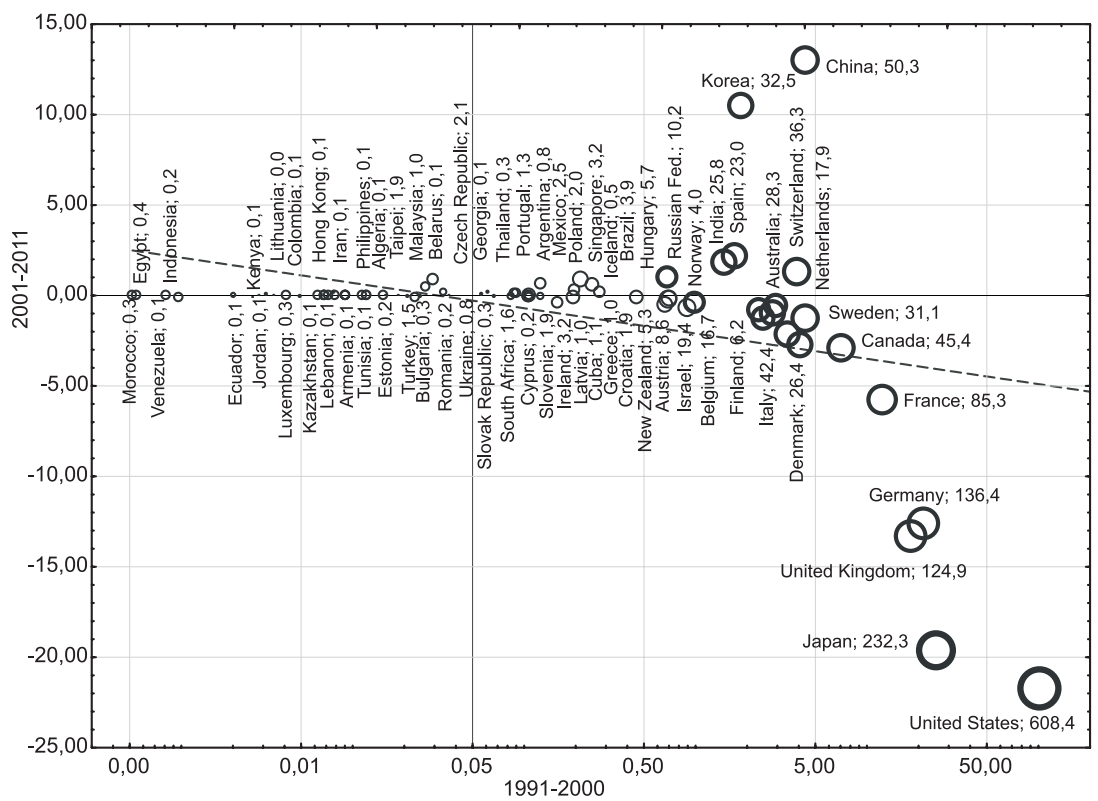

Fig. 6. The number and change in inclination of the value of change in the number of patents in the group of specific therapeutic activity of chemical compounds or medicinal preparations in years 1990-2011

Source: own elaboration based on the data obtained from OECD 
Another notable trend associated with the increasing activity of Asian countries in the pharmaceutical sector is the number of patents in the group specific therapeutic activity of chemical compounds or medicinal preparations according to the International Patent Classification (IPC). By analysing the size and the change in number of patents in years 1990-2011, we notice at first the predominance of developed countries in the number of patents, with the highest number in the United States (608 patents/25 per year), followed by Japan (232 patents/20 per year), as well as Germany and the United Kingdom (Fig. 6). However, when examining the increase in number of patents one can note that these countries reported the highest increase at the end of the twentieth century, but in the twenty-first century they experienced a decreasing trend and were outrun by China and South Korea. Today, other countries with an upward trend in the number of patents in medicine and pharmacy are Switzerland, Spain, India and Russia. Bearing in mind that these are patents covering a wider scope than just pharmacy, we can confirm the previously suggested thesis of relocation process of the pharmaceutical industry in the world.

Besides the relocation of production and of research in the pharmaceutical market, other notable global processes include reduction of drug prices and reduction of drug reimbursement by the state. Governments across the globe are faced with the problem of medical account deficit, related both to economic recession (budget deficit) and the ageing of population (providing medical care). Examples of pricing restrictions may be actions taken by some countries such as France, that introduced a small group of reimbursement drugs covering approximately 10-20\% of medicines; Germany introduced profitability analysis reducing the amount of reimbursement decisions, Spain forced lower prices of medicines along with their reimbursement. Therefore, pharmaceutical companies have adapted their strategies and many of them changed their production profile of basic medicines. Therefore, the most profitable drugs now are cancer drugs, immune and anti-inflammatory drugs. There is a high medical demand for those drugs and their prices are more easily accepted by regulatory authorities. Other activities of pharmaceutical companies aimed at adapting to the new requirements include the introduction of flexible prices adjusted to the market of a given country. Lower drug prices in emerging markets were achieved by reducing the costs of production (e.g. Brazil), tightening of top-down regulation of drug prices (Russia), top-down reduction of prices of medicines (e.g. China - reduction by about $12 \%$ ). These actions will force changes in the global pharmaceutical market in order to maintain the competitiveness of the biggest players. It can be expected that in the coming years there will be an intensification of the pharmaceutical industry relocation caused not only by the growth of markets in the developing countries, but also by the desire to lower drug prices, manufactured in countries with higher labour costs. According to the IMS Institute report: The Global Use of Medicines: Outlook Through 2016, the expenditure in developed markets in the pharmaceutical industry will fall by $57 \%$ due to slower growth in expenditure of pharmaceutical companies and increasing measures to reduce costs borne by taxpayers, which will affect many unprofitable investments, mainly in the sector of niche medicines. The decrease in expenditure on a global basis will be compensated by an increase of $12-30 \%$ in developing countries. This situation will be the result of the economic growth of developing countries. However, even with such 


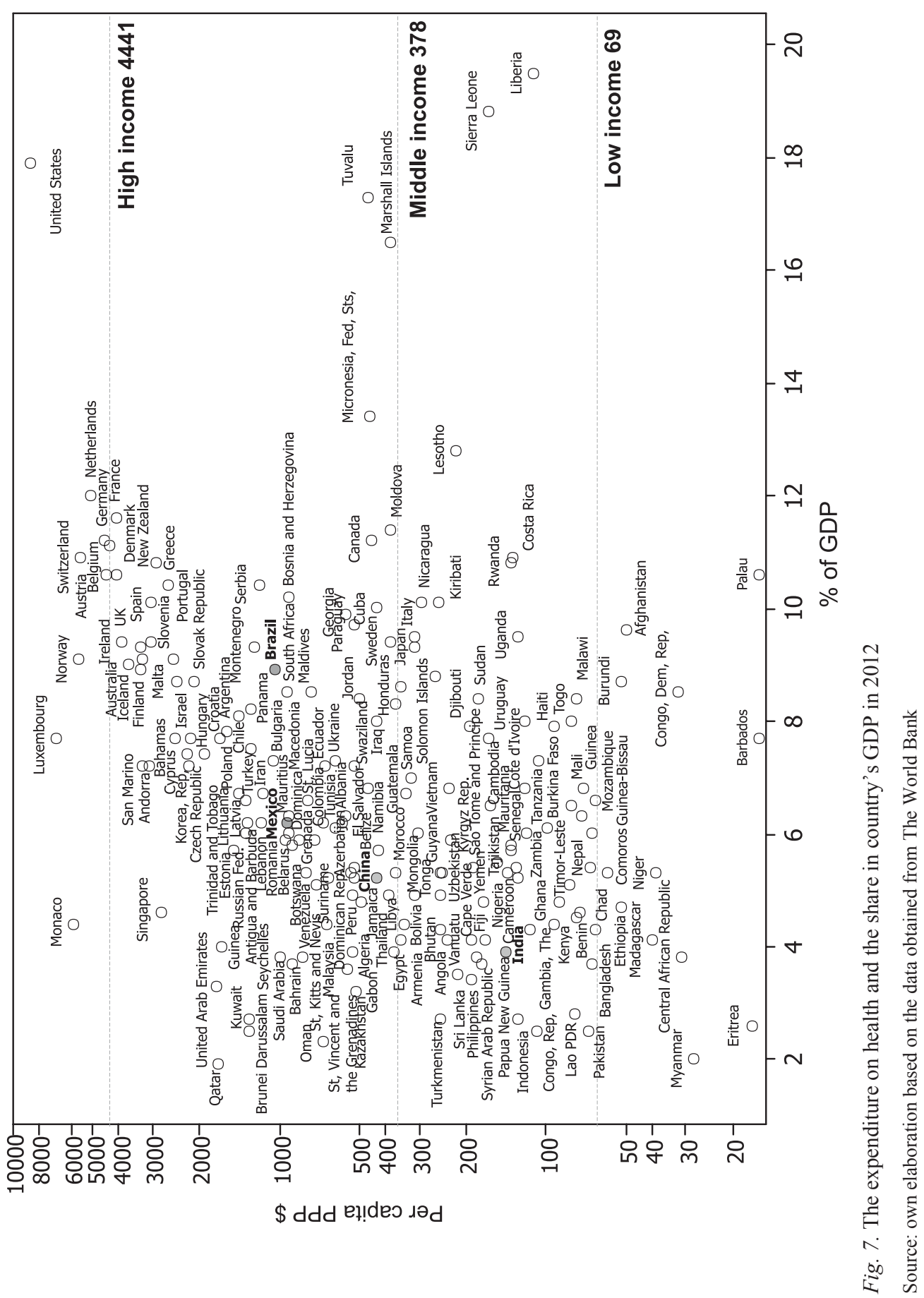


a rapid growth of the pharmaceutical market in the countries of the so-called pharmerging, i.e. mainly in China, Brazil, Russia and India, the difference between the value of expenditure on medicines in these countries and the value of expenditure in developed countries will still be huge. This is particularly evident in the volume of health expenditure per capita and the share of medical sector in the share of GDP of the country. With regard to expenditure on drugs, this relationship is similar, because expenditure on drugs in relation to total health expenditures account for approximately $10-20 \%$ in developed countries (e.g. Canada $9.8 \%$, U.S. 10.3\%, South Korea 14.8\%, Japan 20.6\%), while in the BRIC countries 20-30\% (e.g. Russia 13.6\%, Brazil 17.2\%, India 23.2\%, China 28.0\%).

Tab. 3. Changes in pharmaceutical market in years 2009-2013

\begin{tabular}{|c|c|c|c|c|}
\hline Tiers & \multicolumn{2}{|c|}{ Countries } & $\begin{array}{c}2009 \text { GDP based } \\
\text { on PPP valuation } \\
\text { (Trillion USD) }\end{array}$ & $\begin{array}{l}\text { Incremental Pharma } \\
\text { Market Growth } \\
\text { from 2009-2013 } \\
\text { (Billion USD) }\end{array}$ \\
\hline Tier 1 & \multicolumn{2}{|l|}{ 1. China } & 9 & 40 \\
\hline Tier 2 & \multicolumn{2}{|l|}{$\begin{array}{l}\text { 2. Brazil } \\
\text { 3. Russia } \\
\text { 4. India }\end{array}$} & $2-4$ & $5-15$ \\
\hline Tier 3 & $\begin{array}{l}\text { 5. Venezuela } \\
\text { 6. Poland } \\
\text { 7. Argentina } \\
\text { 8. Turkey } \\
\text { 9. Mexico } \\
\text { 10. Vietnam } \\
\text { 11. S. Africa }\end{array}$ & $\begin{array}{l}\text { 12. Thailand } \\
\text { 13. Indonesia } \\
\text { 14. Romania } \\
\text { 15. Egypt } \\
\text { 16. Pakistan } \\
\text { 17. Ukraine }\end{array}$ & $<2$ & $1-5$ \\
\hline
\end{tabular}

Source: Pharmaceuticals \& Biotech Industry Global Report - 2011. IMAP Healthcare Report

In view of changes in the pharmaceutical market value (Tab. 3) along with the rapid growth of the pharmaceutical market in developing countries (mainly BRIC), disparities in expenditure on health should be cleared off.

An addition to the analysis of the global pharmaceutical market is the contribution of individual countries in the international medicine exchange. The presented list of the volume of drugs export shows the unquestioned dominance of Germany, whose exports account for an average of $14.6 \%$ of the total world exports and even increased by $0.5 \%$ in the analysed period. Germany is followed by Belgium and Switzerland with an average exports share of $11.8 \%$ and $10.0 \%$. These countries also recorded an increase in their share in exports by more than $2 \%$ in the analysed period. More than $8 \%$ of market share in the average value of global exports of medicines belong to the United States $(8.8 \%)$, France $(8.1 \%)$ and the UK $(8.0 \%)$, however, their share is declining. This decline in the USA was $1.5 \%$ and in France $1.8 \%$, while in the UK more than $2 \%$. Also other countries: Ireland, Italy, Netherlands, Spain, Denmark and Sweden, whose average share in exports during the analysed period amounted to more than $2 \%$ of global exports (together these countries accounted for $22.5 \%$ of world exports of medicines), reported a decrease or a minimal increase in their share in exports. 


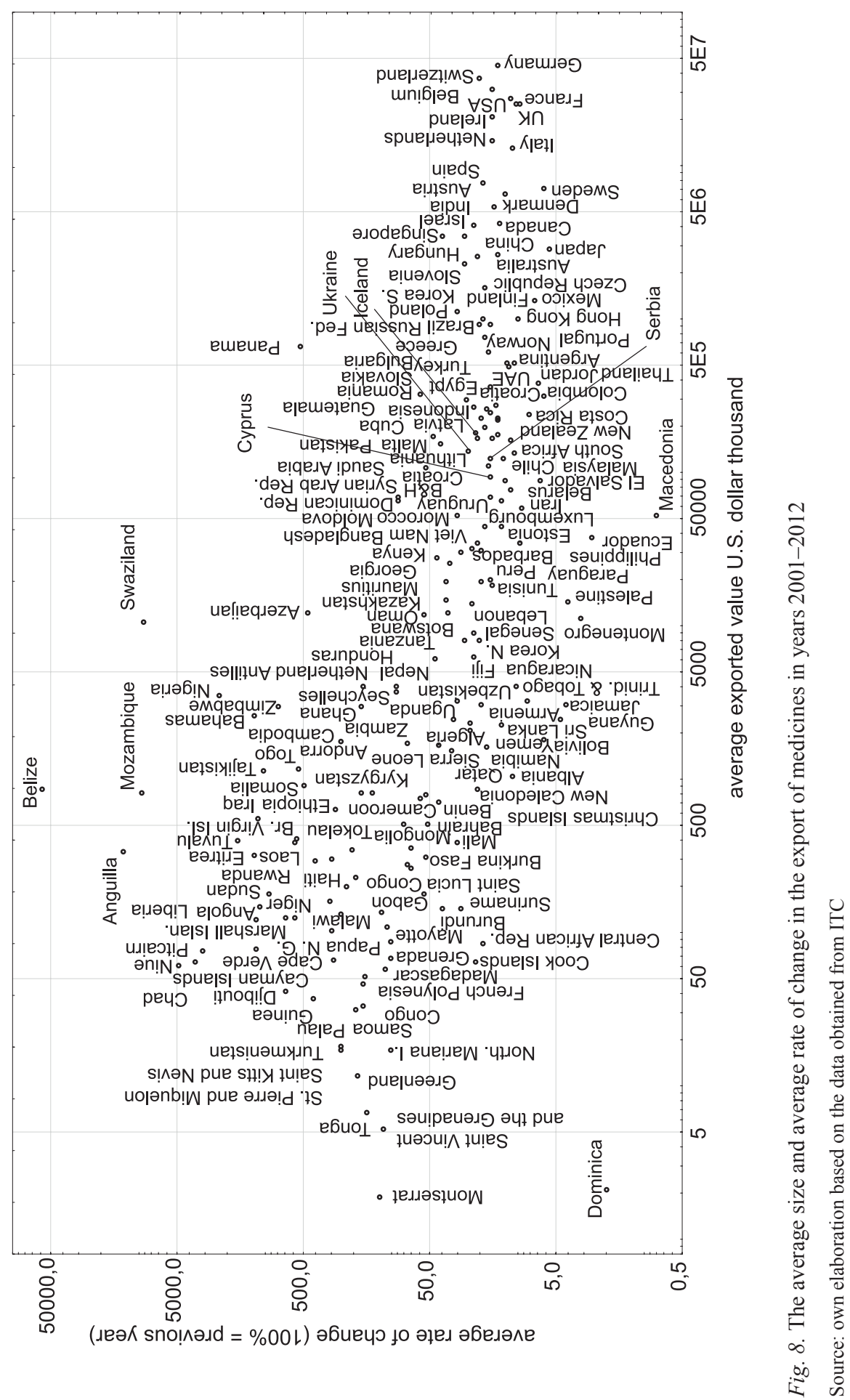


The only exception was Spain, which saw a $0.9 \%$ increase in the share in exports. However, due to the lack of investment and economic crisis and according to the analyses of the pharmaceutical industry in Spain, it may experience a decline in export of drugs that are based on low production costs and prices of offered goods (Vogler et al., 2011).

Non-European countries with an average of $0.9 \%-1.2 \%$ of the value of exports of drugs in years 2001-2012 were India, Singapore, Israel, China, Canada, Australia and Japan. These countries, except Canada and Japan, have seen a slight increase in their share in world exports of medicines, with the highest - approximately 1\% - in Singapore.

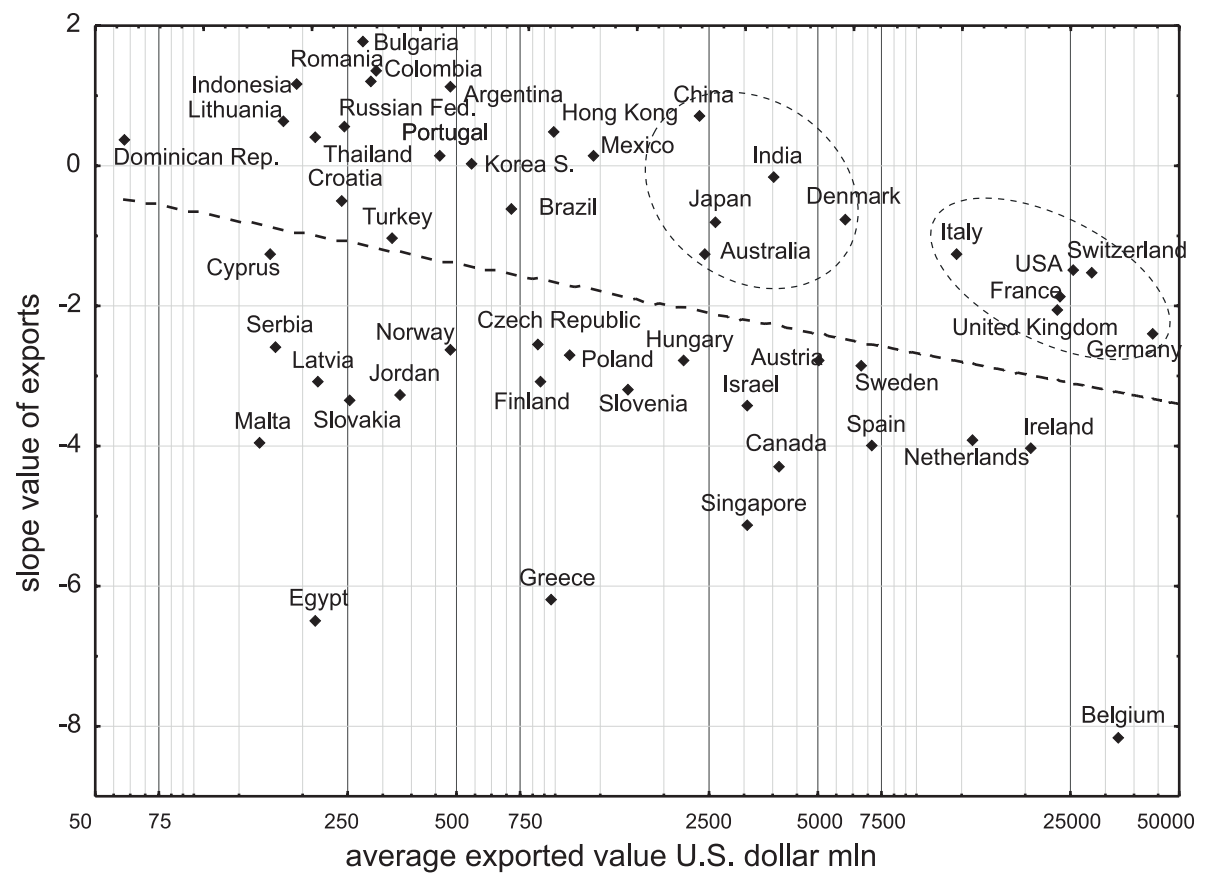

Fig. 9. The average size and inclination of the rate of change of drug export in years 2001-2012 in fifty largest exporters of drugs in the world

Source: own work based on the data obtained from ITC

Referring to the average annual change in the size of export of medicines for all countries during the first decade of the twenty-first century, there was an increase of $13.5 \%$ compared to the previous year. The largest increase of over $100 \%$ was reported in countries with minimal participation in the international drug market, and achieving such high values by those countries was due to their very small potential at the beginning of the century. However, it can be seen that a higher increase occurred in countries with small or medium share in world exports of drugs, mostly in non-European countries (Latin America, Middle East, Africa). Among European countries the largest increase was reported in Romania (58\%), Moldova (48\%), Poland (30\%), Hungary and Bulgaria (26\%), Bosnia and Herzegovina (23\%), 
Lithuania and the Czech Republic (21\%), which are in the region of Central and Eastern Europe. Other countries with a high growth rate of exports of medicines are Israel $(26 \%)$, Uzbekistan (24\%), India and Russia (22\%) and China (21\%). The developed countries of Western Europe did not exceed the level of $21 \%$ (Belgium $-20.1 \%$ ) increase in the value of exports (Sweden recorded the lowest growth of 6.3\%).

To demonstrate the trend of changes, indicator of changes in the inclination of the export of medicines in years 2001-2011 was used, showing 50 countries that account for $99.2 \%$ of world exports. The positive growth trend was recorded mainly by countries with an average value of exports below 500 million U.S. dollars (Fig. 9). These were the countries from Central and Eastern Europe (Bulgaria, Romania, Lithuania, Russia), Latin America (Colombia, Dominican Republic and Argentina) and Asia (Indonesia and Thailand). Portugal was also in this group as the sole representative of Western Europe. Other countries with positive growth trend values are China and Hong Kong, Mexico and South Korea. Negative values of growth (min. -3) belong to the countries with the highest export value of medicines. They can be put into two groups: to the value (-1): India, Denmark, Japan and Australia, and the second group with exports value over 1 billion U.S. dollars and the decline up to the value of (-3): Italy, USA, Switzerland, France, the United Kingdom and Germany. The first group also includes countries with a lower value of exports: Turkey, Brazil, Croatia and Cyprus. These are the countries showing a similar trend in changes in the volume of exports as the largest world exporters. The largest decrease in export of medicines is, however, independent of the volume of exports and the region of the world. The largest downward trend was recorded in Belgium, the leader of international drug market, and in Greece and Egypt, with a small share in the international drug market. In comparison with the previously presented data on global trends in changes of location of the pharmaceutical industry, it can be concluded that in developing countries a large part of production goes to the home market, which is a stimulant for the development of this sector of their economies. At the same time, there is a process of changing the direction and volume of international trade, noticeable also in drug exports.

The present trend of relocation of the pharmaceutical industry in the world is connected with relocation of manufacturing plants and research institutions rather than with relocation of registered offices of pharmaceutical companies. According to the number and value of transactions of property in the pharmaceutical market in 2010, the first place belonged to the United States with 114 transactions worth 25.6 million USD. The next was Germany with 18 transactions worth 5.4 million USD. Further came the emerging markets: India (48 transactions worth 4.9 million U.S. dollars), China (105 transactions with the value of 3.8 million USD) and Brazil (13 transactions worth 1.9 million USD). In developing countries such as China most transactions are micro-transactions with the value of less than 20 million USD (Pharmaceuticals \& Biotech Industry Global Report - 2011). In the list of transactions in 2011, changes in share or ownership in the pharmaceutical market occurred mainly between the major players: USA and Western Europe (Tab. 4). 


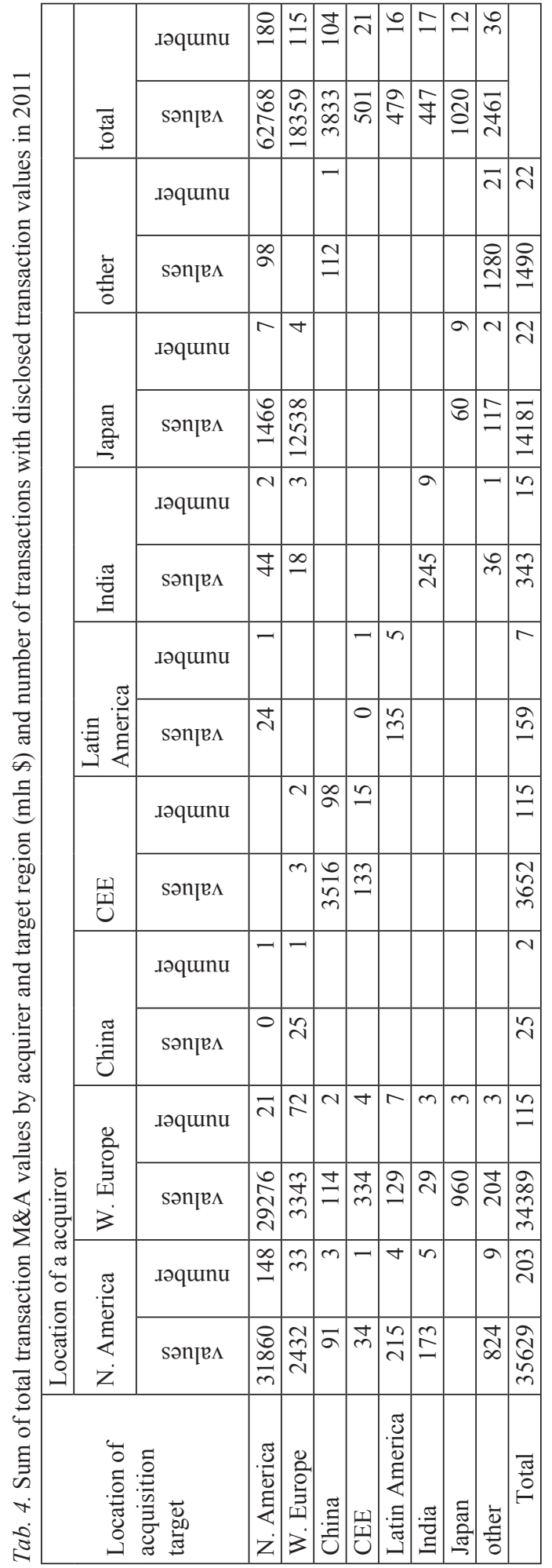

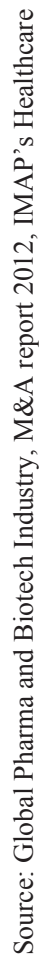




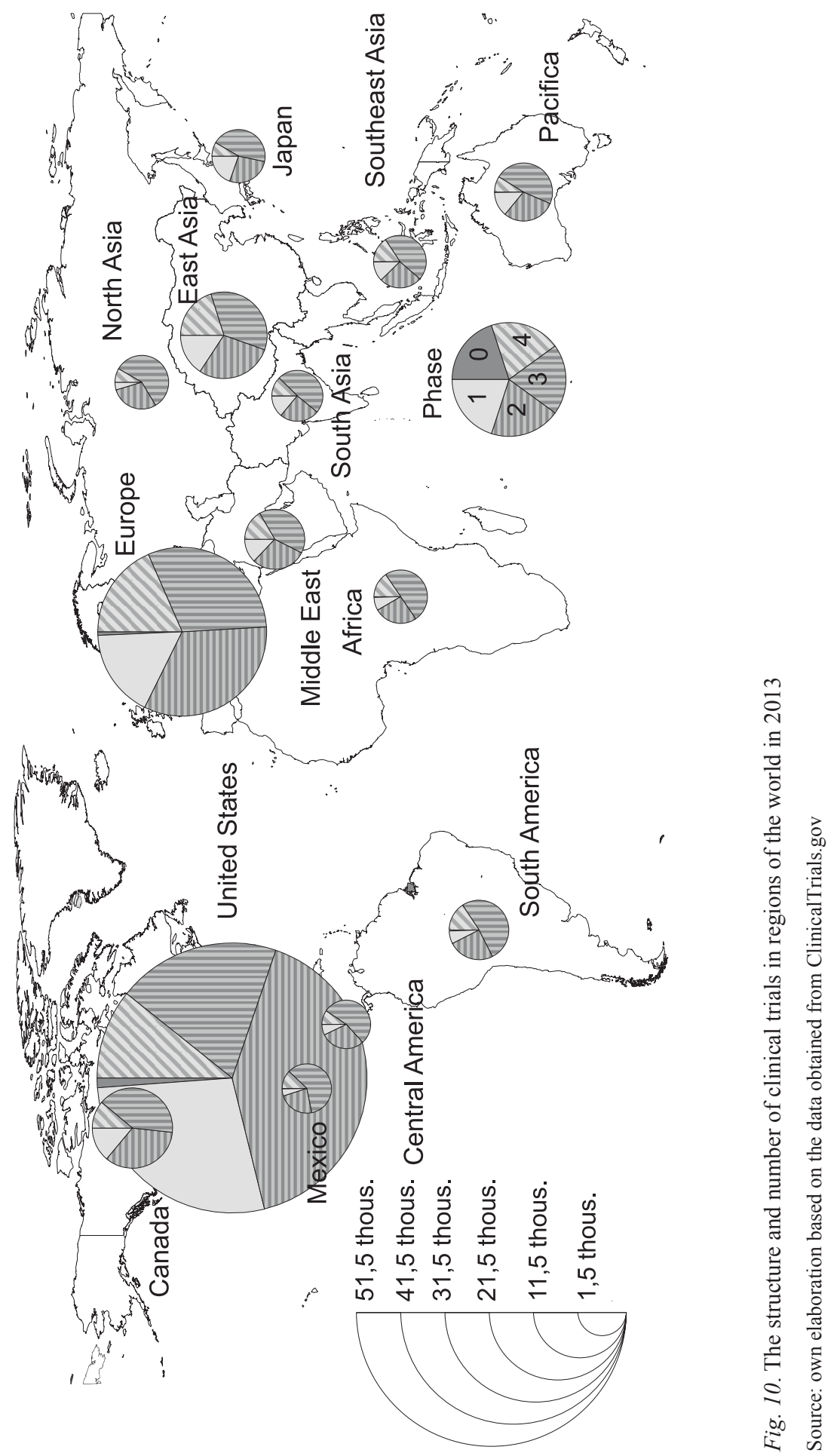




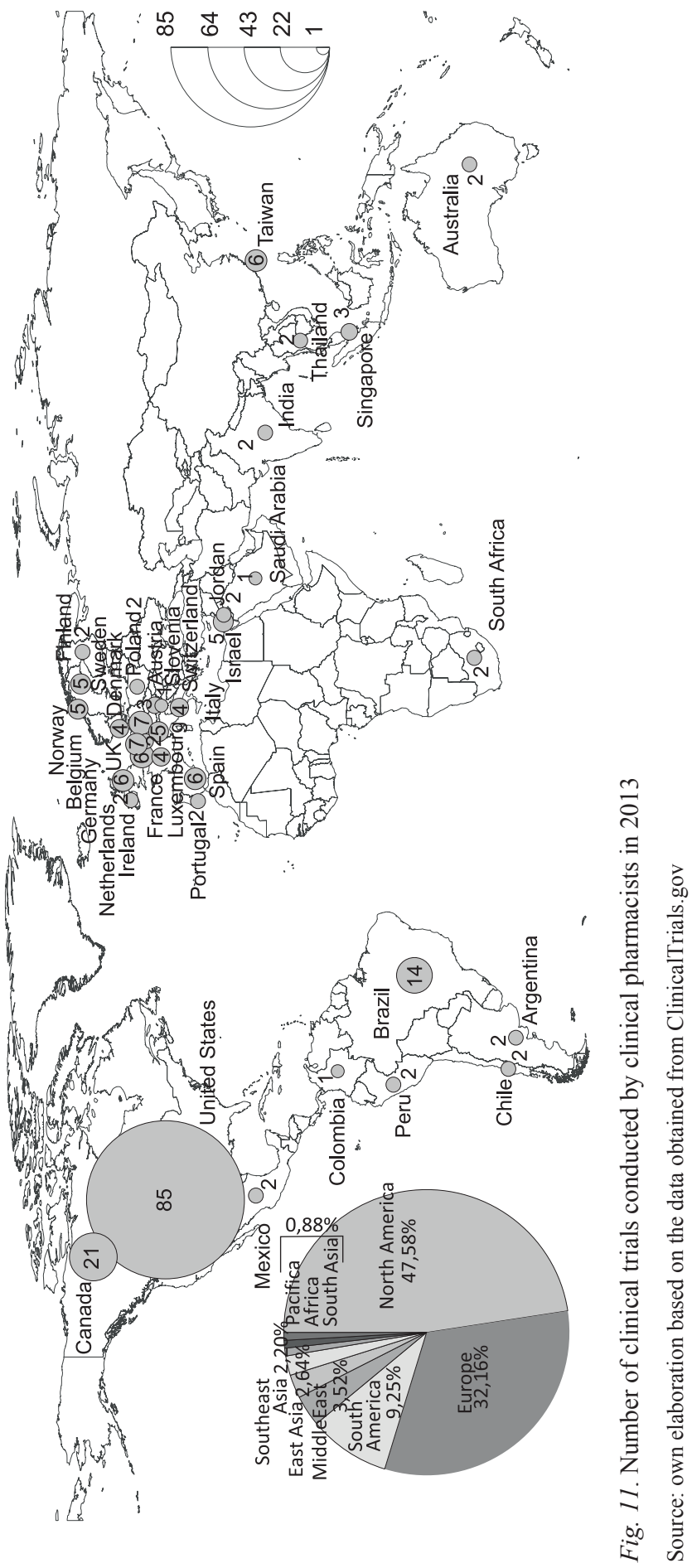


It can be assumed that, along with the development of the pharmaceutical market, pharmaceutical production is relocated to developing countries, along with the research base.In the case of the pharmaceutical industry, these changes can be observed in distribution of clinical trials, which are an essential process in introduction of any new drug on the market. Clinical examination, as mentioned in the earlier part of this article, is one of the most costly and most innovative stages of drug production. Analysing the distribution of clinical trials clearly shows the clear dominance of the United States, where approximately $28 \%$ of 183,768 trials registered in ClinicalTrials.gov web portal are located (Fig. 10). The next region by the number of clinical trials is Europe, with about $16 \%$ share. These regions have the largest share in the most innovative research phase, which is the originator zero and first phase, and the last one: fourth phase. Analysing the share of various phases of clinical trials, we will notice high innovation in the Asian region, which is associated with relocation of research centres.

Referring to the strictly pharmacological clinical trials related to the number of tests conducted by clinical pharmacists, the dominance of the United States can also be seen. In 2013 there were 85 clinical trials involving this specialization located in the USA out of the total 233 clinical trials registered in the world. Overall in North America (including Canada and Mexico) there was approximately $46 \%$ of global clinical trials in the field of pharmacy.The next important region in terms of clinical trials was Europe with 73 clinical trials. European countries that stand out in this respect and should also be pointed out are Germany and Belgium with 7 cases of clinical trials, and Spain, the UK and the Netherlands with 6 clinical trials. Among the rest of the world, Brazil took the third place with 14 studies, after the United States and Canada (21 studies). In this analysis, it can be seen that judging by the number of highly advanced innovative processes, such emerging economic powers like China, India and Russia, are lagging behind the world leaders in pharmacy. However, Brazil should be pointed out, because it has become one of the major players in pharmaceutical market in the world in recent years.

\section{CONCLUSions}

Analysing the current trends of development of the pharmaceutical industry it should be noted that the process of its development is long and difficult to predict, which results in its very high investment risk. In the initial stage of clinical trial and basic research, the undertaken actions are non-linear (the basic research is holistic), therefore it is difficult to set clear time frames and to determine the costs and profits derived from the findings. Given the unpredictable times and high costs associated with establishing new research centres, decisions about making new investments are very difficult. Additional factors affecting the consolidation of clinical trials are historical conditioning and low mobility of academic staff, often associated with a given university. Therefore, considering the location of research centres associated with the first phase of the creation of new drugs, there is a visible dominance of the U.S. and Western Europe, and to a lesser extent also Central and Eastern Europe. 
However, global changes related to markets and production costs affect the growth of the emerging economies' share in the pharmaceutical market, mainly in the BRIC countries. It should be noted that the development of the pharmaceutical industry in these countries is done with a large involvement of public institutions and state support. In China and Brazil, the development of the pharmaceutical industry was entered into the innovative strategy for the development of these countries at the beginning of the twenty-first century. It is related to the fact that the pharmaceutical industry, next to the communications industry, is currently the most innovative sector of the economy. It is indicated by the volume of investments in R\&D as a percentage of income from selling goods. In the United States, where $80 \%$ of the world production of drugs is located, this share is about $17-20 \%$, while in the telecommunications industry the share amounts to $15 \%$, and in the computer industry only $5 \%$. This fact results in continuous increase in spending on research and development in this sector.

Referring, therefore, to the assumption that innovative economy based on knowledge and generating scientific progress is what gives competitive advantage to individual countries, the conclusion must be drawn that the phaCrmaceutical industry is one of the driving wheels of the economic development of countries and regions. Nowadays there are generally two main trends in the development of the global pharmaceutical sector. One of them is the relocation of manufacturing from developed countries to developing countries. This is a result of both: growing demand for pharmaceutical products in developing countries, as well as the desire to reduce costs of production, especially during the global economic crisis, which by reimbursement decisions of governments strongly influences the drug market. Another process is relocation of activities related to research on new pharmaceuticals. However, in this case, the most innovative research phase, the initial phase, is still located in the former centres, mainly in the U.S. and Western Europe. However, with the financial possibilities of economies such as India or China, it is expected that in coming years also this stage of research will be attracted by the growing emerging markets. Another factor stimulating the development of pharmaceutical sector in developing countries is a receptive drug market, functioning mainly on imports and based on support provided by the governments of these countries, that often allows operation, even if there is a high investment risk.

Therefore, it can be concluded that in the pharmaceutical industry the relocation of the various stages of production of drugs takes place from the least to the most innovative, from the region of the Western world through Western Europe towards South and East Asia and Latin America.

\section{References}

Calo-Fernández, B., Martínez-Hurtado, J. (2012). Biosimilars: Company Strategies to Capture Value from the Biologics Market. Pharmaceuticals, 5(12), 1393-1408. DOI: 10.3390/ph5121393.

Dorocki, S., Jastrzębski, J. (2012). Regionalne zróżnicowanie rozwoju biotechnologii w Europie. Prace Komisji Geografii Przemystu Polskiego Towarzystwa Geograficznego, 20, 67-94. 
Dorocki, S., Świętek, A. (2013). Uwarunkowania rozwoju usług opartych na wiedzy, na przykładzie analizy działalności gabinetów stomatologicznych w Polsce. Prace Komisji Geografii Przemystu Polskiego Towarzystwa Geograficznego, 21, 348-365.

Gierańczyk, W., Rachwał, T. (2012). Structural changes in the industry of Poland against the background of eastern European Union states. Quaestiones Geographicae, 31(2), 83-93.

Herper, M. (2013). The Cost of Creating A New Drug Now \$5 Billion, Pushing Big Pharma To Change. Retrieved from http://www.forbes.com/sites/matthewherper/2013/08/11/how-the-staggering-cost-of-inventing-new-drugs-is-shaping-the-future-of-medicine/.

Herper, M. (2013). How Much Does Pharmaceutical Innovation Cost? A Look At 100 Companies. Retrieved from Forbes, 2013/08/11. Retrieved from http://www.forbes.com/sites/matthewherper/2013/08/11/the-cost-of-inventing-a-new-drug-98-companies-ranked/.

Higgins, M.J., Rodriguez, D. (2006). The outsourcing of R\&D through acquisitions in the pharmaceutical industry. Journal of Financial Economics, 80(2), 351-383. DOI: 10.1016/j.jfineco.2005.04.004.

Howells, J., Gagliardi, D., Malik, K. (2008). The growth and management of R\&D outsourcing: evidence from UK pharmaceuticals. R\&D Management, 38, 205-219. DOI: 10.1111/j. 1467-9310.2008.00508.x.

Kaplan, W.A., Wirtz, V.J., Stephens, P. (2013). The Market Dynamics of Generic Medicines in the Private Sector of 19 Low and Middle Income Countries between 2001 and 2011: A Descriptive Time Series Analysis. PLoS ONE, 8(9): e74399. DOI:10.1371/journal.pone.0074399.

Kilar, W. (2008). Zatrudnienie w działalności badawczej i rozwojowej jako czynnik rozwoju gospodarki opartej o wiedzę. Przedsiębiorczość - Edukacja, 4, 60-69.

Kilar, W. (2009). Koncentracja przestrzenna światowych firm informatycznych. Prace Komisji Geografii Przemystu Polskiego Towarzystwa Geograficznego, 12, 97-108.

Kwanghui, L. (2004). The relationship between research and innovation in the semiconductor and pharmaceutical industries (1981-1997). Research Policy, 33, 287-321.

Malorye, A. (2012). Reinventing clinical trials. Nature Biotechnology, 30, 41-49. DOI:10.1038/ nbt.2083.

McCamish, M., Woollett, G. (2012). The State of the Art in the Development of Biosimilars. Clinical Pharmacology \& Therapeutics, 91(3), 405-417. DOI:10.1038/clpt.2011.343.

Morgan, S.G. (2006). Prescription Drug Expenditures and Population Demographics. Health Services Research, 41(2), 411-428. DOI: 10.1111/j.1475-6773.2005.00495.x.

Pharmaceuticals \& Biotech Industry Global Report - 2011. IMAP Healthcare Report.

Rachwał, T. (2003). Globalne uwarunkowania restrukturyzacji przedsiębiorstw Polski PołudniowoWschodniej. Prace Komisji Geografii Przemystu Polskiego Towarzystwa Geograficznego, 6, $129-138$.

Rachwał, T. (2013). Rola przedsiębiorstw przemysłowych w rozwoju gospodarki opartej na wiedzy. Prace Komisji Geografii Przemystu Polskiego Towarzystwa Geograficznego, 21, 189-211.

Raźniak, P. (2012). Procesy społeczno-ekonomiczne w Krakowskim Obszarze Metropolitalnym. Prace Geograficzne, 129, 63-81.

Raźniak, P. (2013). Zależność pomiędzy miejscem w międzynarodowych hierarchiach miast a poziomem usług turystycznych. Prace Komisji Geografii Przemystu Polskiego Towarzystwa Geograficznego, 24, 76-90.

Research and Development in the Pharmaceutical Industry. (2006). The Congress of the United States.

Scannell, J.W., Blanckley, A., Boldon, H., Warrington B. (2010). Diagnosing the decline in pharmaceutical R\&D efficiency. Nature Reviews Drug Discovery, 11, 191-200. DOI:10.1038/nrd3681.

Schipper, I., Weyzig, F. (2008). Ethics for Drug Testing in Low and Middle Income Countries. Considerations for European Market Authorisation. Amsterdam: SOMO.

Schipper, I. (2009). Clinical Trials in Developing Countries. Brussels: European Parliament. 
Somnath, P. (2013) Shifts in the Generic-Drug Market: Trends and Causes. U.S. Pharmacist, 38(6) (Generic Drug Review suppl.), 6-10.

Tobolska, A., Matykowski, R. (2006). Działalność przemysłowa w warunkach wzrastającej internacjonalizacji i globalizacji na przykładzie wybranych produktów. Prace Komisji Geografii Przemystu Polskiego Towarzystwa Geograficznego, 8, 47-59.

Toole, A. (2012). The Impact of Public Basic Research on Industrial Innovation: Evidence from the Pharmaceutical Industry. Research Policy 41(1), 1-12. DOI: 10.1016/j.respol.2011.06.004.

Vogler, S., Zimmermann, N., Leopold, C., de Joncheere, K. (2011). Pharmaceutical policies in European countries in response to the global financial crisis. Southern Med Review, 4(2), 69-79. DOI: $10.5655 /$ smr.v4i2.1004.

Weyzig, F. (2004). Sector profile of the pharmaceutical industry. Amsterdam: SOMO.

Zioło, Z. (2006). Zróżnicowanie światowej przestrzeni przemysłowej w świetle koncentracji siedzib zarządów wiodących korporacji. Prace Komisji Geografii Przemystu Polskiego Towarzystwa Geograficznego, 8, 9-26.

Sławomir Dorocki, Ph.D., Department of Entrepreneurship and Spatial Management, Institute of Geography, Pedagogical University of Cracow. Sławomir Dorocki, graduated from Pedagogical University of Cracow, MA degree in geography, Ph.D. in history (Institute of European Studies of the Jagiellonian University). Adiunkt (assoc. professor) at Pedagogical University of Cracow, Institute of Geography. His research interests are tied with regional problems and processes of socio-economic regionalization, with particular emphasis on the diversity of Europe, processes of European integration and historical conditions.

\section{Adres/address:}

Pedagogical University of Cracow

Department of Entrepreneurship and Spatial Management

Institute of Geography

ul. Podchorążych 2, 30-084 Kraków, Poland

e-mail: sdorocki@up.krakow.pl 